\title{
IMPACT OF STATE SUPPORT MECHANISMS ON THE COST OF RENEWABLE ENERGY PROJECTS: THE CASE OF DEVELOPING COUNTRIES
}

\author{
GALINA S. CHEBOTAREVA \\ Academic Department of Energy and Industrial Enterprises Management Systems, Ural Federal University, Russia
}

\begin{abstract}
The effective investment of private capital in renewable energy projects is impossible without intensive and comprehensive support for investors from the state. However, each mechanism of state support is characterized by its own level of risk. Political instability may lead not only to the loss of investment, but also to a decrease in the investment attractiveness of renewable energy projects. This paper summarizes the main types of state support mechanisms, as well as their impact on the development of renewable energy sources (RES) around the world. As a result of the analysis, the types of investors in the global RES market are identified, taking into account their attitude to risk and profit. The paper presents an approach to assessing the level of impact of state support mechanisms on the cost of RES projects based on the evaluation of a system of investment indicators. The calculations are made using Russian RES projects as an example and taking into account their energy and regional features. The results of the study will be used for the development of a methodology for the comprehensive assessment of the effectiveness and appropriateness of state support measures for RES in developing countries, as well as for supplementing the existing approach to the study of competition in the global energy market with a deterministic assessment of the relevant risk.

Keywords: energy, renewable energy sources, state support of RES, risks, investment project, investment attractiveness, project cost, global energy market, developing countries, economic capital.
\end{abstract}

\section{INTRODUCTION}

The development of renewable energy under the conditions of strong competition with conventional energy technologies is always accompanied by active state support. However, earlier studies and expert surveys [1]-[4] showed that the most dangerous risks in this sector are the ones caused by various political factors [1], [2], such as:

- Risks of sudden changes in the strategy of renewable energy sources (RES) development and schemes for its support: complete overhaul, scrapping of the present support scheme, retroactive changes in the support scheme. This reduces the effectiveness of the renewable energy development mechanisms.

- Financial aspects of investors' dependence on state programs. This is due to instability in the volume or duration of such support.

- Regulatory risk, i.e. flaws in legislation: the emergence of legal obstacles to the participation of independent electricity producers, the absence of an independent regulatory body, the lack of comprehensive accounting of all risks, etc.

The risks caused by political factors have a huge impact on the investment attractiveness of RES projects, especially on their costs. Therefore, there is a difficult and urgent need to conduct not only a theoretical but also an applied study of the level of influence of state support mechanisms on the development of renewable energy. This study was conducted on RES projects in developing countries; the developing countries are those countries that are characterized by a high degree of economic dependence on developed countries and are not members of the Organisation for Economic Co-operation and Development (e.g. Russia). 
The result of the study is the systematization and theoretical evaluation of the effectiveness of RES support mechanisms in the global market, as well as the identification of specific investors in the industry, taking into account their attitude towards such projects. The paper presents a practical assessment of the cost of renewable energy projects in developing countries on the basis of a system of traditional and industry-specific indicators. The comparative assessment of the suitability of support mechanisms for RES in developing countries is based on these calculations. The obtained results have practical importance and will be used to develop a deterministic approach to assessing the risks caused by political factors in the field of RES, and its integration into the concept of studying competition in the global energy market.

\section{FEATURES OF SUPPORT MECHANISMS FOR RENEWABLE ENERGY PROJECTS: GLOBAL EXPERIENCE}

An examination of the global and Russian renewable energy markets [5]-[9] showed that these markets are influenced by specific support mechanisms. Initially, a relatively low investment attractiveness of RES required government incentives. The worldwide practice of feed-in tariffs was supplemented with the idea of providing support based on the RES capacity charge. Later on, mechanisms for selling the capacity of RES generators through annual competitive selection of investment projects were introduced; a range of target indicators for the period 2014-2020 and later were established in the Resolution of the Russian Government [10] and RUSNANO [11]. Developing countries, like the majority of developed countries, do not have a system of direct government subsidies for renewable energy.

Table 1 (based on Ermolenko et al. [1], Dia-Core Project [2], Brummer [12], Hayes and Goodarzi [13]) summarizes the main mechanisms of state support for RES in the global market, and provides a short description of these mechanisms and the results of the assessment of their impact on the development of renewable energy in certain regions.

A comprehensive description of the main investors in the renewable energy market, taking into account their specific features - the role, duration of participation in projects, as well as risk and profit ratio - is presented in Table 2 [1], [2].

\section{ESTIMATION METHOD FOR THE COST OF RENEWABLE ENERGY INVESTMENT PROJECTS}

The proposed method for estimating the cost of RES projects is based on the calculation of a set of indicators while taking into account the peculiarities of the state support mechanisms for the sector in developing countries. The specific feature of the method is that each mechanism is characterized by an individual level of risk which affects the final cost of the RES project.

This method includes five steps, as shown in Fig. 1.

The following indicators are used as the key pointers for RES project cost estimation:

- Weighted average cost of capital (WACC) shows how the cost of project financing changes under the influence of support mechanisms.

- Economic capital (risk capital) shows how the amount of capital required to cover project risks changes in case of default [14], [15].

Possible additional indicators are presented in Table 3. 
Table 1: Mechanisms of state support for RES.

\begin{tabular}{|c|c|c|c|c|}
\hline Mechanism & \multicolumn{2}{|c|}{ Short description and features } & $\begin{array}{l}\text { Common } \\
\text { occurrence }\end{array}$ & $\begin{array}{l}\text { Influence on the development } \\
\text { of RES in selected countries }\end{array}$ \\
\hline Feed-in tariff & $\begin{array}{l}\text { Fixed tariff (usually } \\
\text { for small RES } \\
\text { objects) }\end{array}$ & \multirow[t]{2}{*}{$\begin{array}{l}\text { Price is fixed by the } \\
\text { state above the } \\
\text { average market price }\end{array}$} & \multirow{2}{*}{$\begin{array}{l}\text { France, Austria, } \\
\text { Latvia, } \\
\text { Lithuania, } \\
\text { Bulgaria, } \\
\text { Ireland, } \\
\text { Luxembourg, } \\
\text { Greece, } \\
\text { Hungary, } \\
\text { Slovakia, China, } \\
\text { Russia }\end{array}$} & \multirow{2}{*}{$\begin{array}{l}\text { Within } 13-15 \text { years, Austria } \\
\text { becomes one of the EU } \\
\text { leaders in RES utilization } \\
\text { (hydro and bioenergy) thanks } \\
\text { to preferential tariffs }\end{array}$} \\
\hline Feed-in premium & \begin{tabular}{|l|} 
Preferential tariff \\
depending on \\
market electricity \\
prices (usually for \\
large RES facilities)
\end{tabular} & & & \\
\hline $\begin{array}{l}\text { Trading of } \\
\text { renewable energy } \\
\text { certificates }\end{array}$ & $\begin{array}{l}\text { Assignment of } \\
\text { quotas of RES } \\
\text { consumption }\end{array}$ & \begin{tabular}{|l|} 
Market participants \\
undertake obligations \\
for the production, \\
transmission or \\
distribution of \\
renewable energy
\end{tabular} & $\begin{array}{l}\text { Sweden, Poland, } \\
\text { Romania, } \\
\text { Russia }\end{array}$ & $\begin{array}{l}\text { In Sweden, the acquisition of } \\
\text { renewable energy certificates } \\
\text { led to RES share in total } \\
\text { generation exceeding } 50 \%\end{array}$ \\
\hline $\begin{array}{l}\text { Tenders and } \\
\text { auctions }\end{array}$ & \begin{tabular}{|l|} 
Competitive form \\
of selection of \\
projects for the \\
supply of electricity \\
under specified \\
conditions \\
\end{tabular} & $\begin{array}{l}\text { Aimed only at } \\
\text { supporting large } \\
\text { projects }\end{array}$ & $\begin{array}{l}\text { Almost all EU } \\
\text { countries, UK }\end{array}$ & $\begin{array}{l}\text { Lower energy costs for end } \\
\text { users }\end{array}$ \\
\hline Solar obligations & $\begin{array}{l}\text { Support for the } \\
\text { production of heat } \\
\text { energy using only } \\
\text { solar energy }\end{array}$ & \multirow{2}{*}{$\begin{array}{l}\text { List of documents } \\
\text { regulating the } \\
\text { obligations as to the } \\
\text { volume of heat } \\
\text { production }\end{array}$} & \multirow[t]{2}{*}{$\begin{array}{l}\text { Denmark, } \\
\text { Greece, France, } \\
\text { Germany, } \\
\text { Ireland, etc. }\end{array}$} & \multirow{2}{*}{$\begin{array}{l}\text { Introduction of solar thermal } \\
\text { energy into district heating } \\
\text { systems. } \\
\text { Wider use of geothermal } \\
\text { plants }\end{array}$} \\
\hline $\begin{array}{l}\text { Technology-neutral } \\
\text { obligations }\end{array}$ & \begin{tabular}{|l|}
$\begin{array}{l}\text { Support for heating } \\
\text { technologies }\end{array}$ \\
\end{tabular} & & & \\
\hline $\begin{array}{l}\text { Grants, preferential } \\
\text { loans, tax incentives }\end{array}$ & \multicolumn{2}{|c|}{$\begin{array}{l}\text { One-time support to compensate investors } \\
\text { for initial investment costs (on a } \\
\text { competitive basis). } \\
\text { Tax benefit for } 1 \mathrm{kWh} \text { of energy produced } \\
\text { by the RES facility, provided for up to } 10 \\
\text { years (production tax credit) }\end{array}$} & $\begin{array}{l}\text { Almost all EU } \\
\text { countries, UK }\end{array}$ & $\begin{array}{l}\text { Growing number of large } \\
\text { renewable energy projects }\end{array}$ \\
\hline Green subsidies & \multicolumn{2}{|c|}{$\begin{array}{l}\text { Aimed at supporting environmental } \\
\text { activities within RES projects }\end{array}$} & $\begin{array}{l}\begin{array}{l}\text { Almost all } \\
\text { countries }\end{array} \\
\end{array}$ & \begin{tabular}{|l|} 
Improved environmental \\
sustainability of RE
\end{tabular} \\
\hline $\begin{array}{l}\text { Development of } \\
\text { cooperation between } \\
\text { EU countries }\end{array}$ & \multicolumn{2}{|c|}{$\begin{array}{l}\text { Based on the "Covenant of Mayors for } \\
\text { climate and energy" - the mechanisms of } \\
\text { mutual assistance in achieving EU targets }\end{array}$} & $\begin{array}{l}\text { All EU } \\
\text { countries }\end{array}$ & $\begin{array}{l}\text { Energy efficiency } \\
\text { improvements, } 40 \% \text { reduction } \\
\text { in emissions }\end{array}$ \\
\hline $\begin{array}{l}\text { Renewable Heat } \\
\text { Premium Payment }\end{array}$ & \multicolumn{2}{|c|}{$\begin{array}{l}\text { Payments to households for the buying of } \\
\text { appropriate equipment }\end{array}$} & UK & \multirow[t]{2}{*}{$\begin{array}{l}\text { Used for the first time in the } \\
\text { world to support RE heat }\end{array}$} \\
\hline $\begin{array}{l}\text { Renewable Heat } \\
\text { Incentive }\end{array}$ & \multicolumn{2}{|c|}{$\begin{array}{l}\text { Households or enterprises that install } \\
\text { small-scale heating systems receive a fixed } \\
\text { amount determined by the thermal } \\
\text { performance of the RES installation }\end{array}$} & UK & \\
\hline $\begin{array}{l}\text { Cooperation } \\
\text { between EU and } \\
\text { non-EU countries }\end{array}$ & \multicolumn{2}{|c|}{$\begin{array}{l}\text { Enabling legislative and financial policies, } \\
\text { loans, subsidies and grants, tax incentives }\end{array}$} & $\begin{array}{l}\text { All EU } \\
\text { countries }\end{array}$ & $\begin{array}{l}\text { Creation of agencies working } \\
\text { on the principle of "one } \\
\text { window" to assist in } \\
\text { implementation of business } \\
\text { startups in the field of RES }\end{array}$ \\
\hline $\begin{array}{l}\text { Green Patent Pilot } \\
\text { Program }\end{array}$ & \multicolumn{2}{|c|}{$\begin{array}{l}\text { Acceptance of patent applications in the } \\
\text { field of RES }\end{array}$} & USA & $\begin{array}{l}\text { Acceleration of acceptance of } \\
\text { applications for patents in the } \\
\text { field of RES }\end{array}$ \\
\hline $\begin{array}{l}\text { Centers of Energy } \\
\text { Innovations }\end{array}$ & \multicolumn{2}{|c|}{$\begin{array}{l}\text { Involving the best experts to team-based } \\
\text { interdisciplinary projects for the } \\
\text { development of clean energy technologies }\end{array}$} & USA & Growing expert engagement \\
\hline
\end{tabular}


Table 2: Features of investors in the global RES market.

\begin{tabular}{|c|c|c|c|c|}
\hline Type of investors & Degree of involvement & Level of risk acceptance & $\begin{array}{l}\text { Required level of } \\
\text { income }\end{array}$ & $\begin{array}{l}\text { Duration of } \\
\text { participation in the } \\
\text { project }\end{array}$ \\
\hline $\begin{array}{l}\text { Large power- } \\
\text { generating } \\
\text { companies }\end{array}$ & $\begin{array}{l}\text { Creation of } \\
\text { subsidiaries for the } \\
\text { development of RES } \\
\text { projects }\end{array}$ & $\begin{array}{l}\text { All risk acceptance - } \\
\text { preference for long-term } \\
\text { projects }\end{array}$ & $\begin{array}{l}\text { Estimate the cost } \\
\text { of energy } \\
\text { produced }\end{array}$ & $\begin{array}{l}\text { Involved at all stages } \\
\text { of the project, long- } \\
\text { term investors }\end{array}$ \\
\hline $\begin{array}{l}\text { Municipal power } \\
\text {-generating } \\
\text { companies } \\
\text { (MPGC) }\end{array}$ & $\begin{array}{l}\text { State-provided } \\
\text { incentives for } \\
\text { participation }\end{array}$ & $\begin{array}{l}\text { Partial risk acceptance - } \\
\text { participation in joint } \\
\text { projects with } \\
\text { experienced developers, } \\
\text { minimizing the } \\
\text { borrowed funds, work } \\
\text { on the geographic } \\
\text { location of the MPGC }\end{array}$ & $7-9 \%$ per annum & $\begin{array}{l}\text { Involved at all stages } \\
\text { of the project, long- } \\
\text { term investors }\end{array}$ \\
\hline $\begin{array}{l}\text { Original } \\
\text { equipment } \\
\text { manufacturer } \\
\text { independent } \\
\text { energy producers }\end{array}$ & $\begin{array}{l}\text { Holding a controlling } \\
\text { stake }\end{array}$ & \multicolumn{2}{|c|}{ Striving for high risk and high profitability } & $\begin{array}{l}\text { Participate in design, } \\
\text { construction and } \\
\text { operation of power } \\
\text { plants }\end{array}$ \\
\hline Producers & $\begin{array}{l}\text { Investment in projects } \\
\text { for the sale of } \\
\text { equipment }\end{array}$ & \multicolumn{2}{|c|}{$\begin{array}{l}\text { Selection of economically viable projects } \\
\text { only }\end{array}$} & $\begin{array}{l}\text { Up to } 2-3 \text { years after } \\
\text { commissioning }\end{array}$ \\
\hline $\begin{array}{l}\text { Infrastructure } \\
\text { investment funds }\end{array}$ & $\begin{array}{l}\text { Passive investors, joint } \\
\text { participation with } \\
\text { experienced operators }\end{array}$ & $\begin{array}{l}\text { Risk avoidance - work } \\
\text { in well-known markets, } \\
\text { with trusted investors, } \\
\text { joint participation with } \\
\text { experienced operators, } \\
\text { complex risk } \\
\text { management procedures }\end{array}$ & $\begin{array}{l}6-15 \% \text { per } \\
\text { annum }\end{array}$ & $\begin{array}{l}\text { From installation } \\
\text { launch phase until full } \\
\text { repayment of } \\
\text { investments }\end{array}$ \\
\hline $\begin{array}{l}\text { Private } \\
\text { investment funds }\end{array}$ & $\begin{array}{l}\text { Active investors, } \\
\text { providing financial, } \\
\text { engineering and } \\
\text { contact expertise }\end{array}$ & $\begin{array}{l}\text { Accept high risks - } \\
\text { non-recourse loans, } \\
\text { capital-intensive } \\
\text { projects }\end{array}$ & $\begin{array}{l}15-25 \% \text { per } \\
\text { annum }\end{array}$ & $\begin{array}{l}\text { Investment stage, } \\
\text { completion of } \\
\text { construction within } \\
3-7 \text { years }\end{array}$ \\
\hline $\begin{array}{l}\text { Pension capital } \\
\text { funds and } \\
\text { insurance } \\
\text { companies }\end{array}$ & $\begin{array}{l}\text { Full control of the } \\
\text { assets }\end{array}$ & $\begin{array}{l}\text { Conservative risk - } \\
\text { conservative use of } \\
\text { borrowed funds, the } \\
\text { desire to ensure greater } \\
\text { profitability and work } \\
\text { with mature } \\
\text { technologies }\end{array}$ & $\begin{array}{l}5-10 \% \text { per } \\
\text { annum }\end{array}$ & $\begin{array}{l}\text { Start of participation } \\
\text { is at the time of } \\
\text { commissioning before } \\
\text { the end of the asset } \\
\text { life cycle ( } 20-30 \\
\text { years) }\end{array}$ \\
\hline YieldCos & $\begin{array}{l}\text { Acquisition and } \\
\text { ownership of RES } \\
\text { project assets in the } \\
\text { form of a separate } \\
\text { company }\end{array}$ & $\begin{array}{l}\text { High sensitivity to risks, } \\
\text { almost no use of } \\
\text { borrowed funds, transfer } \\
\text { of individual risks to } \\
\text { insurance companies }\end{array}$ & Debt rate & $\begin{array}{l}\text { Construction phase } \\
\text { and up to three } \\
\text { subsequent years to } \\
\text { reach the set level of } \\
\text { profitability }\end{array}$ \\
\hline Green bonds & $\begin{array}{l}\text { Debt financing of } \\
\text { low-carbon } \\
\text { technologies }\end{array}$ & $\begin{array}{l}\text { Existence of risks due to } \\
\text { lack of strict legislation } \\
\text { for their regulation }\end{array}$ & $\begin{array}{l}\text { Average market } \\
\text { rate }\end{array}$ & Entire lifecycle \\
\hline $\begin{array}{l}\text { Asset-backed } \\
\text { securities }\end{array}$ & $\begin{array}{l}\text { Formation of a pool of } \\
\text { assets in RES projects, } \\
\text { conversion of illiquid } \\
\text { assets into a portfolio } \\
\text { of traded securities }\end{array}$ & $\begin{array}{l}\text { Risk reduction is based } \\
\text { on diversification of } \\
\text { funding sources }\end{array}$ & $\begin{array}{l}\text { Average market } \\
\text { rate }\end{array}$ & $\begin{array}{l}\text { Differ in terms of } \\
\text { release dates }\end{array}$ \\
\hline
\end{tabular}




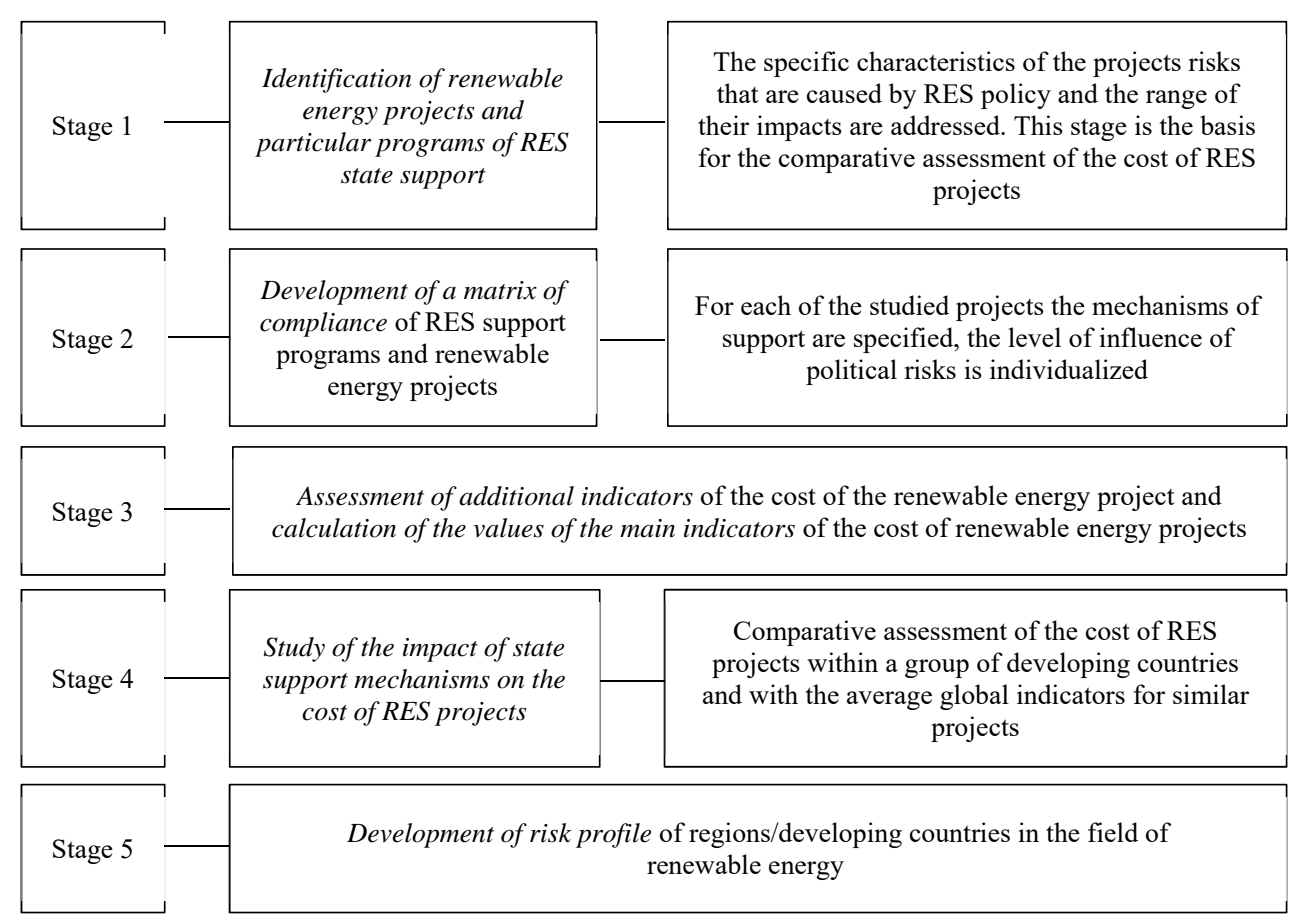

Figure 1: Estimation method for state support impact on the cost of RES projects.

Table 3: Additional indicators of projects' cost evaluation.

\begin{tabular}{|l|l|l|}
\hline Main indicators & Weighted average cost of capital & Economic capital \\
\hline Additional & - Debt/equity ratio & - Probability of default (PD) \\
indicators & - Cost of debt (CoD) & - Loss given default (LGD) \\
& - Cost of equity (CoE) & - Exposure at default (EAD) \\
& - Return on equity (RoE) & - Maturity (M) \\
\hline
\end{tabular}

Evaluation of WACC is based on eqn (1) [2], [16]:

$$
W A C C=\frac{E}{C} \cdot R O E+\left(1-\frac{E}{C}\right) \cdot(1-T) \cdot r,
$$

where $E$ is Equity Capital; $C$ is total investments; $T$ is the relevant tax rate for the project; and $r$ is the interest rate.

For the purposes of this study, $R o E$ is used as an additional indicator and is calculated using two equations. On the one hand, the calculation is based only on the financial statements according to eqn (2):

$$
R o E=\frac{N I}{E}
$$

where $N I$ is net income. 
On the other hand, the calculation is based on eqn (3) from the position of relation to risk [2], [17]:

$$
R o E=R_{f}+\beta \cdot\left(R_{m}-R_{f}\right),
$$

where $R_{f}$ is risk-free rate; $\beta$ is a measure of risk for diversified investors; and $\left(R_{f}-R_{m}\right)$ is risk premium.

The brief characteristics of additional indicators for economic capital calculations, as well as methods of its evaluation, are presented in Domnikov et al. [14], [18], [20] and Mokhov et al. [15], [19]. The final assessment of economic capital is carried out according to the eqn (4), which is based on the Merton-Vasicek method [20]:

$$
E C=E A D \cdot L G D \cdot\left(N \cdot\left(\frac{N^{-1}(P D)+\sqrt{R} \cdot N^{-1}(\alpha)}{\sqrt{1-R}}\right)-P D\right),
$$

where EC is economic capital; $N$ is the function of standard normal distribution; $R$ is the correlation coefficient of the indicators of the project with the general economic situation; and $\alpha$ is reliability level.

\section{COST EVALUATION OF RUSSIAN PROJECTS FOR RENEWABLE ENERGY}

The main mechanism of support for renewable energy in Russia is the selling of RES power through the annual competitive selection of investment projects (Agreements for the Supply of RES Capacity (CSA (Capacity Supply Agreement) contracts)) [11]. This mechanism is aimed at achieving the target of $4.5 \%$ of production and consumption of renewable energy in Russia by 2024. In this paper, I will assess how the competitive selection mechanism affects the cost of projects.

The selection targets for 2014-2020 determine the priority areas for renewable energy in Russia [10], [21]:

- wind energy: $3.6 \mathrm{GW}$;

- solar energy: $1.52 \mathrm{GW}$;

- small hydroelectric power: $0.75 \mathrm{GW}$.

\subsection{Brief description of renewable energy projects}

The Russian projects selected for evaluation are outlined in Table 4; they match the state priority areas of RES development, and detailed descriptions of the projects can be found in publications by the Analytical Center under the Government of the Russian Federation [22], PJSC "RusHydro" [23] and JC "Fortum" [24].

\subsection{Practical evaluation of the costs of renewable energy projects}

In accordance with the presented method, the costs of Russian renewable energy projects are estimated based on WACC (see section 4.2.1) and economic capital (see section 4.2.2) adjusted to the impact of state support mechanisms.

\subsubsection{Estimation of WACC of renewable energy projects}

The input data for the estimation of the WACC of RES projects are presented in Table 5.

The results of the evaluation of the WACC of RES projects are presented in Table 6. 
Table 4: Characteristics of evaluated Russian renewable energy projects.

\begin{tabular}{|c|c|c|c|}
\hline Project characteristics & $\begin{array}{l}\text { Orsk solar power } \\
\text { plant }\end{array}$ & $\begin{array}{l}\text { Binary block on } \\
\text { Pauzhetskaya geothermal } \\
\text { power plant }\end{array}$ & $\begin{array}{l}\text { Wind power plant in } \\
\text { Ulyanovsk }\end{array}$ \\
\hline Company-initiator & PJSC “T Plus” & PJSC "RusHydro" & JC "Fortum" \\
\hline Economic region & Ural & Far Eastern & Volga region \\
\hline Installed capacity, MW & 40 & $\begin{array}{l}\text { Increase of station } \\
\text { capacity by } 2.5\end{array}$ & 35 \\
\hline Year of commissioning & 2015 & 2012 & 2018 \\
\hline $\begin{array}{l}\text { Term of putting into } \\
\text { operation, years }\end{array}$ & 2 & 2 & 2 \\
\hline $\begin{array}{l}\text { Project budget, mln. } \\
\text { euro }\end{array}$ & 35 & 7 & 65 \\
\hline $\begin{array}{l}\text { Type of state/regional } \\
\text { support }\end{array}$ & CSA contract & CSA contract & $\begin{array}{l}\text { CSAcontract, } \\
\text { regional support, tax } \\
\text { benefits }\end{array}$ \\
\hline Scheme of financing & \multicolumn{3}{|l|}{ Project finance } \\
\hline $\begin{array}{l}\text { Share of borrowed } \\
\text { capital, \% }\end{array}$ & 80 & 60 & 70 \\
\hline $\begin{array}{l}\text { Cost of borrowed capital } \\
\text { (r), \% per annum }\end{array}$ & 11.18 & 11.13 & 12.20 \\
\hline Credit rating & \multicolumn{3}{|l|}{$\mathrm{BB}+$} \\
\hline Level of reliability $(\alpha)$ & \multicolumn{3}{|l|}{95.125} \\
\hline
\end{tabular}

Table 5: Components of the WACC assessment of RES projects.

\begin{tabular}{|l|l|l|l|}
\hline Additional characteristics & $\begin{array}{l}\text { Orsk solar power } \\
\text { plant }\end{array}$ & $\begin{array}{l}\text { Binary block on } \\
\text { Pauzhetskaya geothermal } \\
\text { power plant }\end{array}$ & $\begin{array}{l}\text { Wind power } \\
\text { plant in } \\
\text { Ulyanovsk }\end{array}$ \\
\hline $\begin{array}{l}\text { Average return on equity (RoE) of } \\
\text { company-initiator during period of project } \\
\text { realization, \% }\end{array}$ & 24.52 & 3.79 & 11.7 \\
\hline $\begin{array}{l}\text { Relevant tax rate for the project (T), \% } \\
\text { without state support }\end{array}$ & 20 & 20 & 20 \\
\hline $\begin{array}{l}\text { Relevant tax rate for the project (T), \% } \\
\text { with state support }\end{array}$ & 20 & 20 & 15 \\
\hline Risk-free rate $\left(R_{f}\right)$ with state support & 8.0 & 8.21 & 9.53 \\
\hline$\beta$ with state support [2], [17] & 1.20 & 1.00 & 1.45 \\
\hline $\begin{array}{l}\text { Risk premium }\left(R_{f}-R_{m}\right), \%[2],[17] \text { with } \\
\text { state support }\end{array}$ & 3.8 & \multicolumn{2}{|l|}{} \\
\hline $\begin{array}{l}\text { Average RoE of company-initiator during } \\
\text { period of project realization, } \% \\
\text { with state support }\end{array}$ & 3.44 & 4.41 & 4.02 \\
\hline
\end{tabular}


Table 6: Estimation of WACC and indicator changes for RES projects.

\begin{tabular}{|l|l|l|l|}
\hline Project title & $\begin{array}{l}\text { Orsk solar power } \\
\text { plant }\end{array}$ & $\begin{array}{l}\text { Binary block on Pauzhetskaya } \\
\text { geothermal power plant }\end{array}$ & $\begin{array}{l}\text { Wind power plant } \\
\text { in Ulyanovsk }\end{array}$ \\
\hline $\begin{array}{l}\text { WACC, \% } \\
\text { without state support }\end{array}$ & 12.06 & 6.86 & 10.34 \\
\hline $\begin{array}{l}\text { WACC, \% } \\
\text { with state support }\end{array}$ & 75.96 & 181.74 & 127.86 \\
\hline$\Delta \mathrm{WACC}, \%$ & +63.9 & +174.88 & +117.52 \\
\hline$\Delta$ RoE, $\%$ & -21.08 & +0.62 & -7.68 \\
\hline$\Delta$ Relevant tax rate, $\%$ & 0 & 0 & -5 \\
\hline
\end{tabular}

WACC: weighted average cost of capital; RoE: return on equity.

The calculations showed that the value of WACC for each project increased several fold. In practice, this means that the cost of project financing under the influence of support mechanisms has become higher. The level of risk caused by state support for renewable energy is too high and reduces the effectiveness of such projects. Expert assessment of WACC for EU countries using the example of wind power [17] showed that its value varies between 5\% and $13 \%$. Russian projects show similar values only in the absence of state support (7-12\%).

\subsubsection{Assessment of the economic capital of RES projects}

The input data for the assessment of the economic capital of the projects studied are presented in Table 7.

Table 7: Components of economic capital assessment of RES projects.

\begin{tabular}{|l|l|l|l|}
\hline Additional characteristics & $\begin{array}{l}\text { Orsk solar power } \\
\text { plant }\end{array}$ & $\begin{array}{l}\text { Binary block on } \\
\text { Pauzhetskaya } \\
\text { geothermal power } \\
\text { plant }\end{array}$ & $\begin{array}{l}\text { Wind power plant } \\
\text { in Ulyanovsk }\end{array}$ \\
\hline $\begin{array}{l}\text { Probability of default (PD), \% } \\
\text { without state support }\end{array}$ & 15 & 10 & 12 \\
\hline $\begin{array}{l}\text { Probability of default (PD), \% } \\
\text { with state support }\end{array}$ & 7 & 3 & 6 \\
\hline Loss given default (LGD), \% & 76.7 & 62.9 & 70.2 \\
\hline $\begin{array}{l}\text { Exposure at default (EAD), mln. } \\
\text { euro (includes loan value, interest } \\
\text { paid, return on equity) }\end{array}$ & 44.73 & 8.11 & 80.66 \\
\hline Maturity (M) without state support & 3.27 & 3.34 & 3.31 \\
\hline Maturity (M) with state support & 3.40 & 3.58 & 3.43 \\
\hline $\begin{array}{l}\text { Correlation coefficient of the } \\
\text { indicators of a project with the } \\
\text { general economic situation (R) }\end{array}$ & 0.25 & 0.2 & 0.35 \\
\hline
\end{tabular}


The impact of state support on the size of the projects' economic capital reduces the probability of default of projects. The probability of default of projects before getting state support is estimated based on the statistical distribution of data from similar projects, after using state support - on the basis of expert evaluation.

The results of the economic capital assessment are presented in Table 8.

The correspondence between the changes in economic capital, probability of default and maturity are presented in Table 9.

Thus, state support led to the growth of the economic capital of each RES project by about 11 million euros. This amount is a quantitative assessment of the possible losses from the risks associated with state support. Despite the fact that the key indicator of the probability of default has been more than halved in each case, the maturity (the penalty for the duration of the investment cycle) has increased by an average of $10 \%$. This indicates an increase in the impact of risks associated with the state impact on the development of each of the RES projects and of political uncertainty.

\section{CONCLUSIONS}

It is widely known that high rates of renewable energy development are achieved mainly due to active state support. Developing countries, along with developed countries, use a wide range of investment support measures for the development of renewable energy technologies, from direct grants and tax benefits to trading of renewable energy certificates and quotas for renewable energy. However, such state policy is accompanied by specific risks, which are mainly due to the instability of such programs, a high level of financial dependence, etc.

Table 8: Evaluation of RES projects' economic capital.

\begin{tabular}{|l|l|l|l|}
\hline Project title & $\begin{array}{l}\text { Orsk solar power } \\
\text { plant }\end{array}$ & $\begin{array}{l}\text { Binary block on } \\
\text { Pauzhetskaya } \\
\text { geothermal power } \\
\text { plant }\end{array}$ & $\begin{array}{l}\text { Wind power plant } \\
\text { in Ulyanovsk }\end{array}$ \\
\hline $\begin{array}{l}\text { Economic capital, mln. euro } \\
\text { without state support }\end{array}$ & 95.36 & 15.33 & 164.93 \\
\hline $\begin{array}{l}\text { Economic capital, mln. euro } \\
\text { with state support }\end{array}$ & 108.48 & 17.71 & 182.56 \\
\hline$\Delta$ economic capital, mln. euro & +13.12 & +2.38 & +17.63 \\
\hline $\begin{array}{l}\text { Changes in economic capital as the } \\
\text { budget share, \% }\end{array}$ & 37.5 & 34 & 27.1 \\
\hline $\begin{array}{l}\text { Changes in economic capital in the } \\
\text { share of borrowed capital, \% }\end{array}$ & 46.9 & 56.7 & 38.7 \\
\hline
\end{tabular}

Table 9: Changes in indicators of the economic capital of RES projects.

\begin{tabular}{|l|l|l|l|}
\hline Project title & $\begin{array}{l}\text { Orsk solar power } \\
\text { plant }\end{array}$ & $\begin{array}{l}\text { Binary block on } \\
\text { Pauzhetskaya } \\
\text { geothermal power } \\
\text { plant }\end{array}$ & $\begin{array}{l}\text { Wind power plant } \\
\text { in Ulyanovsk }\end{array}$ \\
\hline$\Delta$ economic capital, mln. euro & +13.12 & +2.38 & +17.63 \\
\hline$\Delta$ probability of default, \% & -8 & -7 & -6 \\
\hline$\Delta$ maturity & +0.13 & +0.24 & +0.12 \\
\hline
\end{tabular}


The study of the impact of state support mechanisms on the cost of projects was carried out using the example of projects for the construction of solar power, wind power plants and a binary block at a geothermal station being implemented in developing countries. The results showed that the initial theoretically estimated appropriateness of state-provided incentives for the industry is accompanied by a negative quantitative assessment. Thus, a comprehensive assessment of WACC found a rise in the cost of capital projects in the range of 6-26 times. The capital required to cover project risks increased 1.13 times. In the aggregate, this indicates that there is no positive effect from the state incentives for renewable energy. By contrast, state stimulation programs for RES development in EU countries has the opposite (not negative) effect. Consequently, measures to support renewable energy in developing countries are not producing the necessary results, thus reducing the investment attractiveness of renewable energy projects in those countries, given their high economic instability.

Further directions of the research are related to the development of a methodology for the integrated assessment of the effectiveness and suitability of state support for RES in developing countries, quantitative assessment of the relevant risks, and improvement of the methodology for assessing competition in the global energy market. Future research should allow for the comprehensive study of not only the social attractiveness but also the economic attractiveness of RES projects in different regions, to assess the investment potential of different regions and companies in the sector, and to identify the stage at which RES projects no longer need state support.

\section{ACKNOWLEDGEMENT}

The study was supported by a grant from the Russian Science Foundation (project number 17-78-10039).

\section{REFERENCES}

[1] Ermolenko, G.V., Tolmacheva, I.S., Ryapin, I.Y., Fetisova, Y.A., Matshura, A.A. \& Reutiva, A.B., Handbook on Renewable Energy in the European Union, Institute of Energy SRU GSE: Moscow, 96 pp., 2016.

[2] Dia-Core Project, The impact of risks in renewable energy investment and the role of smart policies, http://diacore.eu/results/item/enhancing-res-investments-final-report. Accessed on: 1 Jun. 2018.

[3] Chioncel, C.P., Tirian, G.O., Gillich, N., Hatiegan, C. \& Spunei, E., Overview of the wind energy market and renewable energy policy in Romania. IOP Conference Series: Materials Science and Engineering, 163(1), 2017.

[4] Campatelli, G., Benesperi, F., Barbieri, R. \& Meneghin, A., New business models for electric mobility. IEEE International Electric Vehicle Conference, 2015.

[5] International Renewable Energy Agency (IRENA), Renewable energy statistics 2017, http://www.irena.org/DocumentDownloads/Publications/IRENA_Renewable_Energy Statistics_2017.pdf. Accessed on: 10 Jan. 2018.

[6] International Renewable Energy Agency (IRENA), Renewable energy highlights, http://www.irena.org/DocumentDownloads/Publications/IRENA_Renewable_energy highlights_July_2017.pdf. Accessed on: 10 Feb. 2018.

[7] Renewable Energy Policy Network for the 21st Century (REN21), State of renewable energy 2016. Global report, http://www.ren21.net/wp-content/uploads/2016/10/ EN21_GSR2016_KeyFindings_RUSSIAN.pdf. Accessed on: 11 Feb. 2018.

[8] Renewable Energy Policy Network for the 21st Century (REN21), State of renewable energy 2017. Global report, http://www.ren21.net/wp-content/uploads/2017/10/178399_GSR_2017_KEY-FINDINGS_RU_low.pdf. Accessed on: 20 Mar. 2018. 
[9] Chebotareva, G., Researching the risks of Russian energy companies in the context of renewable energy sources development. WIT Transactions on Ecology and the Environment, 224, pp. 45-56, 2017.

[10] Resolution of the Russian Government, On the mechanism of stimulation of using renewables in the wholesale market of electric energy and power. 28 May 2013, no. 449, http://base.garant.ru/70388616/. Accessed on: 15 Jun. 2018.

[11] RUSNANO, Russian renewable energy, http://www.rusnano.com/upload/images/ sitefiles/files/Presentation_Energy_Efficiency_ENES2013.pdf. Accessed on: 15 Jun. 2018.

[12] Brummer, V., Community energy - benefits and barriers: A comparative literature review of community energy in the UK, Germany and the USA, the benefits it provides for society and the barriers it faces. Renewable and Sustainable Energy Reviews, 94, pp. 187-196, 2018.

[13] Hayes, J.G. \& Goodarzi, G.A., Electric Powertrain: Energy Systems, Power Electronics and Drives for Hybrid, Electric and Fuel Cell Vehicles, 530 pp., 2019.

[14] Domnikov, A., Chebotareva, G. \& Khodorovsky, M., Unbiased investment risk assessment for energy generating companies: Rating approach. International Journal of Sustainable Development and Planning, 12(7), pp. 1168-1177, 2017.

[15] Mokhov, V.G., Chebotareva, G.S. \& Demyanenko, T.S., Complex approach to assessment of investment attractiveness of power generating company. Bulletin of the South Ural State University. Mathematical Modelling, Programming \& Computer Software, 10(2), pp. 150-154, 2017.

[16] Bloomberg, Global trends in renewable energy investment 2016, http://fs-unepcentre.org/publications/global-trends-renewable-energy-investment-2016. Accessed on: 15 Jul. 2018.

[17] Green-X, Modelling risks of renewable energy investments, http://www.greenx.at/downloads/WP2\%20-\%20Modelling\%20risks\%20of\%20renewable\%20energy\% 20investments\%20\%28Green-X\%29.pdf. Accessed on: 15 Jul. 2018.

[18] Domnikov, A., Khomenko, P. \& Chebotareva, G., A risk-oriented approach to capital management at a power generation company in Russia. WIT Transactions on Ecology and the Environment, 186, pp. 13-24, 2015.

[19] Mokhov, V.G., Chebotareva, G.S. \& Khomenko, P.M., Modelling of "green" investments risks. Bulletin of the South Ural State University, Series: Mathematical Modelling, Programming and Computer Software, 11(2), pp. 154-159, 2018.

[20] Domnikov, A., Chebotareva, G., Khomenko, P. \& Khodorovsky, M., Risk-oriented investment in management of oil and gas company value. International Journal of Sustainable Development and Planning, 12(5), pp. 946-955, 2017.

[21] Energy Bulletin, Promotion of renewable energy, http://ac.gov.ru/files/publication/a/ 3822.pdf. Accessed on: 10 Jun. 2018.

[22] Analytical Center under the Government of the Russian Federation, Energy bulletin. Development of solar energy, http://ac.gov.ru/files/publication/a/11725.pdf. Accessed on: 5 Jul. 2018.

[23] PJSC "RusHydro", http://www.rushydro.ru. Accessed on: 5 Jul. 2018.

[24] JC "Fortum", https://www.fortum.ru/. Accessed on: 5 Jul. 2018. 